\title{
Being Emmanuel: Matthew's Ever-Present Jesus?
}

\author{
Markus Bockmuehl, University of Oxford
}

For the Gospel according to Matthew, where is Jesus now? ${ }^{1}$ At least at first sight, the First Evangelist appears very much clearer than Mark concerning the Messiah's origin and birth, as well as his whereabouts after the crucifixion. For example, Matthew leaves no loose ends about an unfulfilled promise of a resurrection encounter in Galilee. More importantly, he stresses the abiding presence of Jesus as a theme that links Jesus's earthly ministry to his risen life, and the Gospel story to the everyday life of the messianic ekklésia. More than either Mark or Luke, Matthew repeatedly formulates pertinent words of Jesus in a form that suggests not merely a single historical locus but a more timeless and abiding address envisaging Jesus in the present, after the resurrection.

I will here concentrate on the three passages that are most widely agreed to document Matthew's emphasis on the present Messiah: the parallel of 1.23 with 28.20, and 18.20.

\section{Emmanuel at His Birth (1.23)}

Matthew is deliberate in his identification of the Messiah's role and origin from the start. In

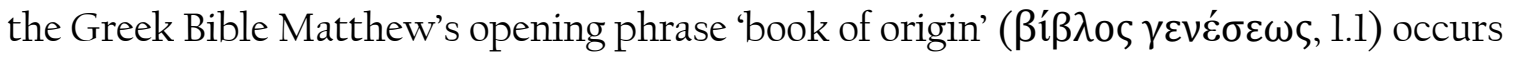
only two other times, designating in the first case the story of creation (Gen 2.4) and in the

\footnotetext{
${ }^{1}$ Early drafts of this material were presented in diverse forms at the Moscow conference 'The Gospel of Matthew in its Historical and Theological Context' (24-28 September 2018), the Oxford New Testament Seminar (12 October 2018) and as part of the 2018 Didsbury Lectures (Manchester, 29 October - 1 November 2018). I gratefully acknowledge feedback and suggestions from audiences on all three occasions, from Evangeline Kozitza Dean and Artur Suski, SJ, as well as from the Editor and an anonymous reviewer for this Journal.
} 
other the account of human civilization (Gen 5.1). This suggests that for Matthew too this expression does not signify merely the genealogy or birth narrative of a hero or sage, but rather introduces his own definitive book of origins. The 'genesis' of redemption through this descendant of David and Abraham is not merely the object of his achievement or a feature of his story, but turns out to be vital for the man's identity. This striking opening gambit already seems patently relevant to the potential challenge that an absent Jesus might in due course represent.

Matthew wastes no time in establishing the identity of Jesus as emphatically that of a present Messiah. First and most programmatically, Matt 1.23 foregrounds our topic even before Jesus is born. He is identified not only as the promised Messiah who represents or channels God's presence, but as bearing the very name which personifies that presence: Emmanuel. The angel's instruction, implemented by Mary and Joseph, is for the child to be named Jesus - 'because he will save his people from their sins' (1.21). And yet, as readers invariably note, Matthew specifically asserts that this birth and naming of the child fulfils a prophecy that 'they shall call his name Emmanuel.'

\footnotetext{
${ }^{2}$ I am less sure than Warren Carter that the function of this presence of 'Emmanuel' is primarily and specifically 'anti-imperial' in intent, much as a relativization and scepticism about imperial power would seem to be a valid and necessary inference. ('The child Jesus is a sign of resistance to imperial power. The name Immanuel

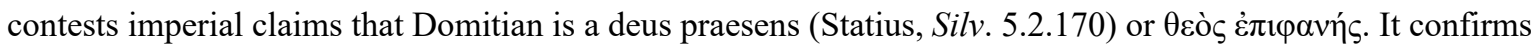
Jesus as the one who manifests God's will and blessings on earth. Through him God's purposes and reign will prevail.' W. Carter, 'Evoking Isaiah: Matthean Soteriology and an Intertextual Reading of Isaiah 7-9 in
} Matthew 1:23 and 4:15-16', JBL 119 (2000) 513.) 
Commentators ever since antiquity have reflected on the seeming contradiction that nobody in this narrative ever names Jesus 'Emmanuel' - either at his birth or at any time thereafter. In fact, Matthew never uses the word again!

Only the most hostile or inattentive of readers would attribute this ostensible contradiction between the story and its first fulfilment quotation to the evangelist's editorial sloppiness. Two incompatible claims are quite plainly placed side by side, and the only plausible explanation must be that this is deliberate. Evidently it matters to Matthew that Jesus is 'Emmanuel - God with us' and yet he does not seem to mind that the angel's instruction about that name is at once roundly ignored by every one of the dramatis personae.

We will see that Emmanuel represents for Matthew not primarily a characterization of the Messiah's birth - though it is that as well. Instead, it marks the abiding identity of Jesus, both before and after the resurrection, even if the narrative never formally makes it his name. As an early reader like John Chrysostom already observed in this text, the event occasions the name just as the name occasions the event: 'Therefore to say "they shall call him "Emmanuel" means nothing other than that "they shall see God among us". To be sure, God has always been among us; but never before so openly.'3

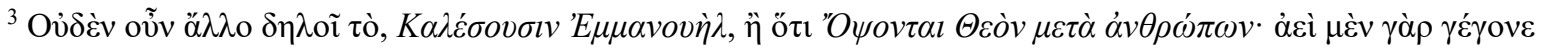

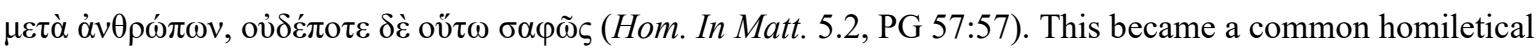
trope in subsequent centuries. Cf. also Lancelot Andrewes' Sermon on 25 December 1614 (L. Andrewes, Ninety-Six Sermons (Library of Anglo-Catholic Theology; 5 vols.; Oxford: Parker, 1841), 1:142): 'St. Matthew knew that well enough, for he sets it down so....Immanuel and Jesus both came to one, as indeed they do; one infers the other.... This name must needs imply a secret antithesis to His former being with us. We say nothing in saying, He is now with us, if $\mathrm{He}$ be not so with us now as never before. With them in types and figures of Himself; His shadow was with them; but now He Himself.'
} 
That opening paradox about what it might mean to say 'God with us' is matched by several others. Elsewhere in the same birth and infancy narrative, readers discover that 'God with us' is an infant king - present to the worship and the royal gifts of the Magi, but nevertheless about to flee the country to become a migrant in Egypt. A further well-known enigma arises when Matthew insists that it is precisely the infant Jesus's flight to refuge in Egypt which fulfils the prophecy, 'out of Egypt have I called my son' (2.14-15). Even his eventual long-term presence in Nazareth leaves a famous exegetical conundrum with its appeal to a 'word of the prophets' (plural but mysteriously unnamed!) that 'he shall be called a Nazorean' (N $\alpha \zeta \omega \rho \alpha i ̃ o \varsigma, 2.23) .{ }^{4}$ As we will see, the paradoxes of Jesus's presence do not end here.

\section{Emmanuel Risen (28.19-20)}

But despite such unexpected challenges, 'Emmanuel' characterizes Matthew's understanding of Jesus throughout this Gospel, as has long been recognized. ${ }^{5}$ This affirmation of the

\footnotetext{
${ }^{4}$ By substituting a prophecy about a 'Nazorean' for Mark's more intelligible usage of 'Nazarene' (e.g. Mark 1.24), Matthew leaves us guessing what passage or indeed what Greek or Hebrew terminology he has in mind. The most plausible association is with the Messiah as the promised Davidic 'Branch' (Heb. netzer) from the exiled stump of Judah; see e.g. Isa 11.1, which was read messianically at Qumran (4Q161 frg 8-10) and in Targum Jonathan. Perhaps Matthew is simply adducing an eschatologically tinged 'folk etymology' of the name 'Nazareth', as e.g. J. Nolland, The Gospel of Matthew: A Commentary on the Greek Text (NIGTC; Grand Rapids: Eerdmans; Bletchley: Paternoster, 2005), 129 implies. Interestingly, Julius Africanus (c. 160-240) associated the relatives of Jesus ( $\delta \varepsilon \sigma \pi$ ó $v v v o$, 'the Lord's people') especially with the villages of Nazareth and Cochaba, both of whose names may have carried messianic associations: see e.g. R. Riesner, “Was kann aus Nazareth Gutes kommen?" (Johannes 1,46): Archäologie und Geschichte des Heimatortes Jesu', TBei 48 (2017) 333-34 and others cited there (n.67).

${ }^{5}$ This is a particular emphasis of D. D. Kupp, Matthew's Emmanuel: Divine Presence and God's People in the First Gospel (SNTSMS 90; Cambridge/New York: Cambridge University Press, 1996), 240 and passim.
} 
Messiah's abiding presence with his people constitutes a deliberate editorial clasp around the Gospel as a whole. It finds its counterpart and matching inclusio in his post-resurrection promise that 'I am with you to the end of the age' (28.20). In other words, he whom the disciples see in Galilee is one and the same as their teacher, continuous with the earthly Jesus in person and by name: $28.16,18 .^{216}$ By the time of this definitive encounter in Galilee, Matthew's Jesus has already appeared in Jerusalem to the two Marys on their way back from the empty tomb (28.9) - an encounter that interestingly parallels the very first verse of Mark's Longer Ending (Mark 16.9).

Matthew reports no disappearance of Jesus, let alone an ascension to heaven. This is because his risen Jesus is already exalted to the divine exercise of 'all power in heaven and on earth' - at God's right hand (cf. 26.64). He does not leave the disciples but remains emphatically 'with you' - present rather than absent. For that reason alone, it seems as if for Matthew no narrative of ascension is even possible. ${ }^{7}$ Instead, the abiding presence of Jesus explicitly encompasses both heaven and earth (28.18) and is perhaps for that reason set on an

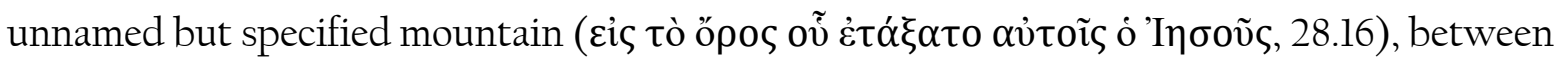
heaven and earth. Commentators sometimes imagine this to designate the Mount of the Sermon (5.1). ${ }^{8}$ But it must be at least equally likely to evoke the Mount of Transfiguration in Matt 17, another unnamed mountain between heaven and earth that hosted a proleptic experience of exalted presence: on his descent from that mountain Jesus 'ordered'

\footnotetext{
${ }^{6}$ Cf. Kupp, Matthew's Emmanuel, 230.

${ }^{7}$ Thus M. Harris, 'The Comings and Goings of the Son of Man: Is Matthew's Risen Jesus “Present” or “Absent”? A Narrative-Critical Response', BibInt 22 (2014) 56, citing C. F. Evans, Resurrection and the New Testament (SBT 2:12; London: SCM, 1970), 83.

${ }^{8}$ See e.g. Nolland, Matthew; cf. W. D. Davies and D. C. Allison, A Critical and Exegetical Commentary on the Gospel According to Saint Matthew (ICC; 3 vols.; Edinburgh: T\&T Clark, 1988-97), 3:681.
} 


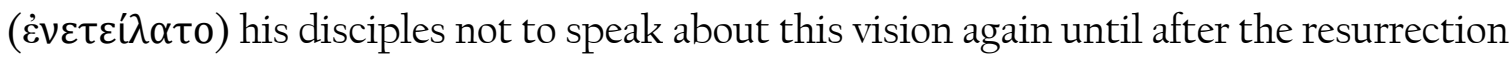
$(17.9) \cdot{ }^{9}$

Matthew thus localizes the risen and exalted Jesus's presence on the Galilean mountain as heavenly and earthly at once. Matthew's interest in geographic as well as symbolic space has repeatedly been noted, not least by Christian Blumenthal in drawing out the spatial realization of God's presence as Immanuel and of the realization of the Kingdom 'on earth as it is in heaven. ${ }^{10}$ Patrick Schreiner has attempted to articulate an approach to this intrinsic ambivalence through the postmodern geographical theory of 'critical spatiality,' arguing that the body of Jesus is itself the space ('thirdspace') in which his presence, and indeed the Kingdom of Heaven, becomes ‘spatially' manifest on earth. This theory of socially constructed space, originally pioneered by Edward Soja, ${ }^{11}$ was previously adopted effectively by Matthew Sleeman in relation to the ascension in the Book of Acts. ${ }^{12}$ It holds evocative potential for Matthew too, even if there are reasons for caution about Schreiner's implementation of the theory.

Schreiner's application of the theory turns out to be rather forceful. He removes the body of Jesus - and indeed the incarnation itself - from the realm of the particular and

\footnotetext{
${ }^{9}$ Similarly Harris, 'The Comings and Goings of the Son of Man', 67.

${ }^{10}$ C. Blumenthal, 'Basileia is Gaining Space: God's Will, Mimesis of Christ, and the Spatial Shaping of the Basileia in Matthew's Gospel', The Gospel of Matthew in its Historical and Theological Context (ed. M. Seleznev et al.; WUNT 459; Tübingen: Mohr Siebeck, 2021), 345-64; cf. C. Blumenthal, Basileia im Matthäusevangelium (WUNT 416; Tübingen: Mohr Siebeck, 2019), 21-29, 153, 164, 203-05.

${ }^{11}$ E. Soja, Thirdspace: Journeys to Los Angeles and other Real-and-Imagined Places (Cambridge, MA/Oxford: Blackwell, 1996).

${ }^{12}$ M. Sleeman, Geography and the Ascension Narrative in Acts (SNTSMS 146; Cambridge/New York: Cambridge University Press, 2009).
} 
experienced to an unlocated place which with Foucault he labels heterotopia, an imaginary place 'outside all places,' 'neither here nor there.'. Equally questionable in Matthean exegetical terms is Schreiner's corollary of a comprehensive replacement theology that does away with the Temple, Roman Empire, and all other literal, sacred, and ideological space ('firstspace,' 'secondspace'), ostensibly in order to unite heaven and earth. We may here leave aside the problematic question of whether even in a qualified sense the kingdom of God is ever properly an 'imagined' space for either the Gospels or their ancient reception. ${ }^{14}$ It seems in any case ironic that Schreiner's complex postmodern theoretical scaffolding in the end reinforces a strikingly old-fashioned set of binary theological premises, extensively drawing in support on analogously tired supersessionist readings of John and Paul. On a related note, some readers have taken exception to the 'colonizing' dimensions of Schreiner's findings: one reviewer worries that this 'thirdspace' body of Jesus 'conquers, contests, infringes upon, declares victory over, pierces, world-builds, overhauls, and establishes....'15

\footnotetext{
13 'Thirdspace,' he writes, 'represents ways in which new meanings and possibilities of spatial practice can be imagined' (P. Schreiner, The Body of Jesus: A Spatial Analysis of the Kingdom in Matthew (LNTS 555; London/New York: Bloomsbury T\&T Clark, 2016), 50), just as Foucault’s concept of heterotopia denotes 'imaginary places outside all places, ... neither here nor there' (53) - like the imaginary games of children. Most strikingly, Schreiner takes this concept beyond Foucault to conclude that the incarnation itself is a heterotopia, i.e. presumably such an imaginary place outside all places, neither here nor there (136). Au contraire: the incarnation marks the quite particular point in space and time where the Word becomes enfleshed - not 'neither here nor there' but among us, for Matthew as much as for John. (Less awkward or demandingly abstract access to Schreiner's desired heterotopic outcome might be available by reading the incarnation as myth).

${ }^{14}$ For Schreiner, this 'Jesus presents an imagined kingdom through his words' (The Body of Jesus, 134, ital. mine).
}

${ }^{15}$ J. P. Grimshaw, review of Patrick Schreiner, The Body of Jesus: A Spatial Analysis of the Kingdom in Matthew (London: Bloomsbury, 2016), BibInt 26 (2018) 289. 
The post-Easter presence of Jesus on the unidentified Galilean ‘high mountain' of Matt 28 does indeed attest a kind of 'thirdspace,' being neither quite heavenly nor quite earthly, but rather in between and both at once. In Matthew that space is, however, 'constructed' (if this is the right word) not 'socially' so much as theologically - that is to say, eschatologically and messianically. This is quite powerfully expressed in the interpretation given in later icons of this mountain and also of the Mount of Transfiguration. ${ }^{16}$

The specific context of the presence of Jesus in Matt 28 is more particularly located in the exercise of discipleship and worldwide mission resulting in baptism and the keeping of his commandments - the Torah of Jesus, as it were. Jesus is present above all in the mission of his followers, especially through his teaching. ${ }^{17}$ That is a point which is strikingly similar in Mark 16.19-20, perhaps reflecting intertextual influence on the Longer Ending.

Once again, his name is his identity: Jesus-Joshua, the 'Saviour' of his people, is also 'God-with-his-people,' Emmanuel (1.23; 28.20). So also baptism in these closing verses is in the 'name' of the triune God who is present (28.19): the Father opens access to the presence of the Son and the Son to that of the Father (cf. already 11.27), just as Father and Spirit were present in the birth and baptism of the Son $(1.18,20 ; 3.16) .{ }^{18}$

\footnotetext{
${ }^{16}$ This correlation is one to which Harris, 'The Comings and Goings of the Son of Man', 67 has also rightly drawn attention in a significant study of this subject. It may also be expressed, perhaps even better than in Foucault or Schreiner, in the recently popularized Celtic notion of particular 'thin places' in which heaven and earth come within touching distance of each other. That said, the point of Matthew's account is arguably to make a more universal claim about the Emmanuel, not to single out or set apart particular 'holy places'.

${ }^{17}$ I owe this insight to a comment received from Carl Holladay.

${ }^{18}$ Cf. similarly M. Karrer, Jesus Christus im Neuen Testament (GNT 11; Göttingen: Vandenhoeck \& Ruprecht, 1998), 308.
} 
Further in relation to Matt 28, some have discerned important typological links in the Pentateuch behind the threefold nexus of commandments, presence, and communityformation that continues from the pre-Easter to the post-Easter Jesus. At Sinai, the giving of the Law similarly connects both with the covenantal constitution of the qahal/ekklésia of Israel and with the presence of YHWH on the mountain and in the tabernacle. ${ }^{19}$ Matthew turned out to be the Evangelist who most nourished the powerful patristic and medieval idea of Christ as the new lawgiver.

\section{Being Emmanuel - An Abiding Presence (18.20)}

This theme of Emmanuel's presence, sustained by the bracket of Matt 1 and 28, comes to expression in several passages, beginning with his opening message about the approaching Kingdom (4.17; cf. 3.1), and, just as emphatically, as a light to the dark lands of the lost northern tribes of Zebulon and Naphtali (4.13-16). For Matthew as for some later Jewish Christians, the Messiah's outreach to these 'lost' tribes became a significant feature of his Galilean mission.

Above all, however, it is in the discourse about the Messianic assembly in chapter 18 that we encounter a permanent ecclesial locus for the presence of Jesus: wherever two or three

\footnotetext{
${ }^{19}$ Kupp, Matthew's Emmanuel, 216-17. P. McDonald, "I Am With You Always, to the End of the Age": Presence in the Gospel according to Matthew', PIBA 28 (2005) 83-84 notes that in a somewhat different vein Moses goes on to pass the baton of God's commissioning presence to Joshua-'Jesus' in the books of Deuteronomy and Joshua. But while the OT Joshua receives the divine promise of presence from Moses, the NT Joshua-Jesus issues it himself, and is himself the new lawgiver here. A deliberate Joshua-Jesus typology has been more persuasively argued for Hebrews (R. J. Ounsworth, Joshua Typology in the New Testament (WUNT 2.328; Tübingen: Mohr Siebeck, 2012)).
} 
gather in his name, there he is among them (18.20). ${ }^{20}$ In context, this promise focuses on Jesus's ratification of the community's disciplinary decision-making - in other words, it reflects his presence specifically as judge, perhaps in a scenario anticipating the image of the juridical throne among twelve thrones in 19.28. The community's function of 'binding and loosing' (18.18), which was in chapter 16 distinctively vested in Simon Peter (16.19), seems in numerous Jewish parallels to denote the teaching authority to declare what is permitted and what is not permitted, including specifically the exercise of discipline and excommunication. ${ }^{21}$ By being equally vested in Peter and in the church as a whole, the presence of Jesus in the exercise of his authority both as teacher and as judge makes Peter's role both unique and at the same time paradigmatic for the church. ${ }^{22}$

Recent studies, however, have rightly questioned attempts to restrict the saying's reach to a narrowly juridical context without reference to Jesus's presence more generally -

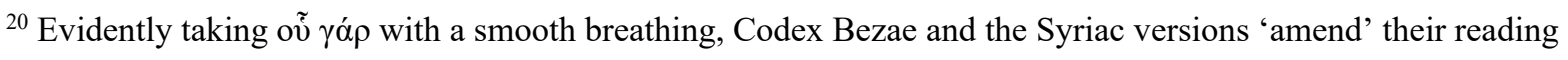
into a double negative form: 'no two or three' will gather in his name anywhere without his presence among

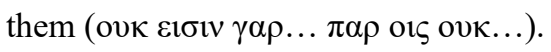

${ }^{21}$ Commentators offer extensive lists of Jewish parallels (e.g. Josephus J. W. 1.111; T. Levi. 18.12; T. Sol. 1.14); for later rabbinic usage cf. also Str-B 1:738-47. See the comprehensive discussion in Davies and Allison,
} Matthew 2.623-41; J. Gnilka, Matthäusevangelium (HTKNT 1.1-2; 2 vols.; Freiburg: Herder, 1986-88), 2:6067; U. Luz, Das Evangelium nach Matthäus (EKKNT 1.1-4; 4 vols.; Zurich: Benziger/Neukirchen-Vluyn: Neukirchener, 1985-2002), 2:461-66. For the theme of church discipline see the re-application of the image in these terms in 18.18; and cf. Acts 5.3, 5, 9. Luz, Matthäus, 2:466 considers both church discipline and the authority to forgive sins to be implicit in the generalizing designation ô čóv ('whatever'), confirmed in 18.18. ${ }^{22}$ So e.g. J. D. Kingsbury, ‘The Figure of Peter in Matthew’s Gospel as a Theological Problem’ JBL 98 (1979) 67-83. Cf. further M. Bockmuehl, Simon Peter in Scripture and Memory: The New Testament Apostle in the Early Church (Grand Rapids: Baker Academic, 2012), 92-94. 
and especially in the church. ${ }^{23}$ Such ratification by Jesus similarly underwrites his more encompassing presence promised for the mission of the church in 28.20.24 (Perhaps 23.10 makes a related affirmation about the continual presence of the Messiah as the church's teacher.)

Matt 18.20 is often thought to evoke a saying attributed in the Mishnah to the early second-century Rabbi Hananyah ben Teradion, according to whom God's presence (Shekhinah) dwells wherever at least two are gathered over words of the Torah. ${ }^{25}$ The Mishnaic text goes on to speak of God himself standing in the midst of those who occupy themselves with the Torah, whether they are ten or even just down to one. ${ }^{26}$ Although in its extant form that rabbinic passage postdates Matthew by well over a century, parallels like these nevertheless suggest that Matthew's Jesus promises his presence to more than just 'the regulation of disputatious church members'. ${ }^{27}$ In our passage, then, Jesus assures his followers of divine ratification and ekklésia-constituting presence.

\footnotetext{
${ }^{23}$ Cf. Kupp, Matthew's Emmanuel; T. J. Surlis, The Presence of the Risen Christ in the Community of Disciples: An Examination of the Ecclesiological Significance of Matthew 18:20 (Tesi Gregoriana: Serie Teologia 188; Roma: Pontificia Università Gregoriana, 2011), 86-88 and passim.

${ }^{24}$ So also P. Pokorny, “"Wo zwei oder drei versammelt sind in meinem Namen...” (Mt 18,20)' Gemeinde ohne Tempel: Zur Substituierung und Transformation des Jerusalemer Temepls und seines Kults im Alten Testament, antiken Judentum und frühen Christentum (ed. B. Ego et al.; WUNT 118; Tübingen: Mohr Siebeck, 1999), 47788.

${ }^{25}$ M.Abot 3.2 שניים שיושבין ויש ביניהם דברי תורה, שכינה שרויה ביניהם (Hananyah b. Teradion).

${ }^{26}$ M.Abot 3.6, there attributed to Hananyah's contemporary Ḥalafta b. Dosa.

${ }^{27}$ Thus rightly Kupp, Matthew's Emmanuel, 199.
} 
To this extent the Mishnah's perspective offers a particularly useful foil for comparison and contrast with Matthew, as Akiva Cohen has demonstrated. ${ }^{28}$ Although separated in time by a little over a century, both documents could be seen as reflecting in cognate but different ways on questions of presence and absence posed by the Temple's destruction. (The comparison arguably remains somewhat relevant even if Matt 24 is dated not long before 70 , reflecting not on a past destruction but on the gathering threat, its dark apprehension compounded by the memory of Caligula's narrowly averted sacrilege and reappropriated predictions of destruction prompted by Jeremiah.)

Matt 18.20 thus constitutes together with 1.23 and 28.20 the core trio of passages that define and energize this evangelist's theme of the presence of Jesus. ${ }^{29}$

\section{Emmanuel Absent?}

But does Matthew intend to posit the abiding presence of Jesus as somehow compensating more specifically for a permanent absence of God from the Temple and, by extension, Jerusalem? Is there a deliberate contrast with its state of 'desolation' in 23.38 as systematic and permanent, rather than punitive but potentially temporary $?^{30}$ The answer to that question

\footnotetext{
${ }^{28}$ A. Cohen, Matthew and the Mishnah: Redefining Identity and Ethos in the Shadow of the Second Temple's Destruction (WUNT 2.418; Tübingen: Mohr Siebeck, 2016), 30 argues that, more than other comparisons, this one usefully correlates two post-70 documents that explicitly reflect 'the reality of a temple-less Judaism which confronted both the authors and their respective communities'. Cohen's conclusion insightfully contrasts what he regards as the Temple's spiritualized continuity in the Mishnah with its spiritualized replacement in Matthew by Jesus and his community - although that divergence also contrasts with interesting elements of liturgical and architectural convergence between church and synagogue during the Byzantine period (pp 516-31).

${ }^{29}$ Kupp, Matthew's Emmanuel, 175 refers to 1.23 as the 'masthead' over the whole gospel.

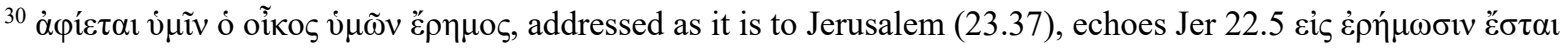

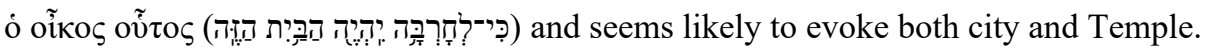


may be less clear than Matthean interpreters typically like to imagine. True, Matthew's Jesus does not explicitly predict his rebuilding of the Temple in three days as John's Jesus does (John 2.19, evidently requiring somewhat laboured reinterpretation). But neither does Jesus in Matthew deny such a prediction on either of the two occasions when he is accused of having made it (in front of Caiaphas and in public on the cross: Matt 26.61; 27.40). And despite the Sanhedrin's best efforts to the contrary (26.59), Matthew unlike Mark ${ }^{31}$ does not label these accusers as 'false'.

A familiar, lazy Christian hermeneutic of 'fulfilment-as-replacement' has long dominated the interpretation of Matt 18.20, and in some quarters continues to do so: if Jesus is present in his church even while the Temple is to be destroyed, then this must mean that Jesus effects not just the spiritual and typological fulfilment but the categorical replacement of Temple, Jerusalem, Zion, and quite possibly Israel itself. ${ }^{32}$ The reasoning appears to be that once the Temple is destroyed, then if Jesus remains present in the church's worship, God must therefore be permanently absent from the Temple, Jerusalem and (by extension?) the synagogue. Contrary to such assumptions, however, Matthew shows no wholesale rejection of Jerusalem, let alone of Israel: The destruction of Jerusalem in no way entails for him the end of Israel. ${ }^{33}$

\footnotetext{
${ }^{31}$ Mark 14.57-59; cf. 15.29.

32 Twentieth century scholarship abounds in examples, and the work of NT Wright is also often cited in this connection. Frequent 'replacement' language also appears from a different theological vantage point e.g. in B. Charette, Restoring Presence: The Spirit in Matthew's Gospel (JPTSup 18; Sheffield: Sheffield Academic, 2000), 101-108 and passim.

${ }^{33}$ So also M. Konradt, 'Die Deutung der Zerstörung Jerusalems und des Tempels im Matthäusevangelium’, Studien zum Matthäusevangelium (ed. A. Euler; WUNT 358; Tübingen: Mohr Siebeck, 2016), 256-57 ('Und
} 
Matthias Konradt nevertheless suggests that when the Emmanuel departs the Temple for the last time and predicts its destruction, this does in some sense entail the presence of God leaving the Temple. ${ }^{34}$ This note of divine departure and absence, foreshadowed of course in Ezek 10-1l and in Jeremiah, is notably also foregrounded by Josephus. ${ }^{35}$ Konradt shares the widespread view that for Matthew, unlike Josephus, the Temple is not just temporarily but permanently 'obsolete'. ${ }^{36}$

Although this is a trope widely repeated in New Testament scholarship since late antiquity, as an interpretation of our text it seems at least prima facie incompatible with Matthew's Mishnah-like perpetuation of Temple-related 'commandments' for the disciples written at a time after (or shortly before?) its destruction. Among these are rules about sacrifices (5.23-24) and tithing, but perhaps also more implicitly concerning the didrachma temple tax (17.24-27), the force of swearing by the altar or the Temple in which God dwells (23.16-21), or the present-tense Sabbath labour of priests in the Temple (12.5), whose intended function as 'a house of prayer' (21.13) is also never in principle abrogated.

To be sure, none of these passages are self-interpreting. All, however, raise worthwhile questions about what, if anything, Matthew assumes to be the future role of the House now 'left desolate' - for example on the day when Jerusalem welcomes Jesus in the name of the Lord (23.38-39).

\footnotetext{
nicht nur für Josephus, sondern auch für Matthäus bedeutet die Zerstörung Jerusalems in keiner Weise das Ende Israels'); cf. 220.

${ }^{34}$ Konradt, 'Die Deutung der Zerstörung Jerusalems', 235.

${ }^{35}$ Most dramatically in J.W. 6.299-300; cf. further 2.539; 5.412; Ant. 20.166.

${ }^{36}$ Konradt, 'Die Deutung der Zerstörung Jerusalems', 252.
} 
It is of course true that by the third and especially the fourth century, the replacement trope had indeed come into its own in Christian polemic. Nevertheless, the use of the Temple's Roman destruction to justify a triumphal narrative of replacement is in fact strikingly absent from the New Testament and appears to surface for the first time after the second-century defeat of another potential attempt to rebuild it: that of Bar Kokhba. ${ }^{37}$ (This may not be accidental, if we take seriously the reapplication by Jesus and others of Jeremiah's prophecies about the destruction of the First Temple: the Scriptural promise of reconstruction after 70 years raises tantalizing questions about expectations in the second quarter of the second century, as Roland Deines has suggested. ${ }^{38}$ )

Hananyah ben Teradion's saying may in fact promise analogous de facto compensation for the Shekhinah's catastrophic absence from the Temple - without of course any implications of categorical 'replacement'. ${ }^{39}$ An almost eucharistic dimension of presence is offered in the very next paragraph of that Mishnaic passage, where three who share words

\footnotetext{
${ }^{37}$ See e.g. Justin, Dial. 16, 108, 133, 136; 1 Apol. 47-48. Even the more explicitly abolitionist and supersessionist Epistle of Barnabas knows of such rebuilding efforts in its own day (16.3-4), but it passes no comment on definitive replacement implications of the year 70. For evidence of initiatives and aspirations to rebuild the Temple under Hadrian, see detailed discussion in W. Horbury, Jewish War under Trajan and
} Hadrian (Cambridge: Cambridge University Press, 2014), 298-307.

${ }^{38}$ R. Deines, 'How Long? God's Revealed Schedule for Salvation and the Outbreak of the Bar Kokhba Revolt', Judaism and Crisis: Crisis as a Catalyst in Jewish Cultural History (ed. A. Lange et al.; SIJD 9; Göttingen: Vandenhoeck \& Ruprecht, 2011), 201-34.

${ }^{39}$ Pokorny, 'Wo zwei oder drei', 479-80 infers that for Matthew by contrast every Christian gathering can therefore become the place of presence. 
of Torah over their meal are presented as if they ate from the table of the Omnipresent Lord himself. 40

Beyond these questions, Matthew also reprises certain wider Marcan themes of Jesus's absence. We may include here his retention of Mark's forward-looking sentiment about fasting in the bridegroom's absence (9.15; cf. Mark 2.19), although chapter 25 suggests that for Matthew the theme of a bridegroom's absence may signal his imminent arrival more prominently than his departure.

Matthew's explanation of his distinctive parable of the weeds appears to insert a more sustained sense of the Son of Man's timeless presence into a story describing at most qualified and temporary absence. This is the one who now, perhaps constantly, sows the good seed (13.37); and this is the one who in the eschaton will send out his angels to select the weeds for destruction in fire (13.41-42). Nevertheless, like the absent Master in the parable of the talents, ${ }^{41}$ the Sower's temporary inattention does give the adversary his disruptive - if ultimately futile - opportunity.

In sending out his disciples on their mission to Israel, Jesus powerfully assures the missionaries both that the sending authority is his own, and indeed that to welcome them is to welcome him by proxy in his absence $(10.16,40)$.

Elsewhere, significantly, the one who is present to accompany their witness before councils and synagogues is not Jesus but the Spirit of God (10.20). The mission to Israel will continue until the coming of the Son of Man (10 .23) - who is now approaching but certainly

\footnotetext{
אבל שלשה שאכלו על שלחן אחד ואמרו עליו דברי תורה, כאלו אכלו משלחנו של מקום ברוך הוא 3.3.

${ }^{41}$ U. Luz, Matthew (Hermeneia; 4 vols. (vol. 1, rev. edn.); Minneapolis: Augsburg Fortress, 2001-2007), 4:259 notes Origen's interpretation of Christ's simultaneous absence and presence according to his human and divine natures (Comm. in Matt. 65, GCS 11:152-53).
} 
still absent (cf. 16.27-28; cf. 24.30-31, 36-44 and passim). The possibility of his timeless presence as the teacher of his disciples (23.10) must be balanced against his evident absence in the face of false messiahs appearing in days to come $(24.23-24,35)$.

It is unclear whether residual Marcan elements of absence could be due to what some Synoptic critics like to call 'editorial fatigue':42 not all the texts just cited are straightforwardly Marcan. Nevertheless, they do somewhat complicate Matthew's assurance of Jesus's abiding presence in chapter 28 - and certainly cast doubt on occasional popularizing attempts to read Matthew as concerned exclusively with the theme of his presence. ${ }^{43}$ Despite its emphatic affirmation, Matthew evidently retains a 'rhetorical sense of ambiguity $^{44}$ about how precisely that presence works.

This ambiguity or paradox of presence and absence proves to be surprisingly complex and diffuse throughout the Gospel. One cluster of questions surrounds assertions about Jesus during his ministry that entail a historically unbounded presence apparently beyond his life on earth. Where, for example, is the voice of Jesus located that offers unexpectedly timeless and transcendentally comforting instruction about rest and relief from burdens in his presence (11.28-30)? ${ }^{45}$ From what vantage point does he utter his curiously diachronic lament for the population of Jerusalem whose treatment of the prophets shows they have always been resistant to his attempts to 'gather' them as a mother bird gathers her chicks (23.37)? The meaning of this latter statement is not of course exhausted by events in his

\footnotetext{
${ }^{42}$ Programmatically in M. Goodacre, 'Fatigue in the Synoptics', NTS 44 (1998) 45-58.

${ }^{43}$ E.g. S. P. Saunders, Preaching the Gospel of Matthew: Proclaiming God's Presence (Louisville: Westminster John Knox, 2010).

${ }^{44}$ Kupp, Matthew's Emmanuel, 199.

${ }^{45} \mathrm{I}$ am not convinced that this mode of presence is best described as 'mystical', pace J. Freeborn, 'The Presence of Christ in Matthew', ExpTim 115 (2004) 156.
} 
lifetime: it speaks rather of the Emmanuel who ministered through the prophets of the past but also now appears as the Exalted One lamenting the imminent or perhaps recent devastation of Jerusalem's 'house' (23.38-39). ${ }^{46}$

Aspects of puzzle and paradox persist even in Matthew's repeated theme of a timeless presence. A few verses before the vital affirmation of 18.20, Jesus has assured the disciples that 'whoever receives one such child in my name receives me' (18.5). The reception of the child in some sense substitutes for the absence of Jesus. But is it the child or the act of reception that mediates his presence, perhaps by some analogy ${ }^{47}$ ? Significantly, Matthew disrupts any straightforward correlation in the very next verse by identifying those children not with Jesus but with his followers - 'these little ones who believe in me' (18.6). ${ }^{48}$

More emphatic still, in the famous eschatological scenario of Matt 25 one of the key criteria of judgment is failure to care for the king's needs when he was hungry, thirsty, a foreigner, destitute, ill, or in prison (25.35-36). 'Finding Jesus in the poor' is a laudably popular and well-loved trope of historic Christian homiletics and praxis, which might seem to hold considerable promise for our topic. Nevertheless there are telling uncertainties and paradoxes about the logic of this Matthean identification, not least because those who truly

\footnotetext{
${ }^{46}$ Note the present tense of $\dot{\alpha} \varphi i_{\varepsilon} \varepsilon \alpha \mathrm{l}$. Many commentators needlessly restrict this predicate's temporal reference. ${ }^{47} \mathrm{Cf}$. the force of the rabbinic term, כאילו e.g. in M. Abot 3.3 immediately after the previously cited passage: three who sit and talk about Torah are 'as if' כאילו they ate at God's own table.

${ }^{48} \mathrm{~A}$ similar and also potentially timeless family connection is present in $12.46-50$, although it remains again somewhat unclear whether this relativization of kinship is a general principle about all families or perhaps relates first and foremost to the biological family of Jesus vis-à-vis his circle of (present and future, v. 50) disciples.
} 
encounter Jesus in this way are unaware of it. ${ }^{49}$ Matthew 25 does affirm a clear bond between Jesus and those deprived of clothes, food, health, friendship, or freedom, even if commentators rightly note that the 'least' among Jesus's brothers and sisters are here in the first instance the poor among his disciples $(25.40,45)$.

In some sense, then, to serve the 'least' is indeed to serve Jesus himself. However, as with the child in 18.5, we may wonder if this is for Matthew an ontological or more of a relational equivalence. In other words, does the presence of Jesus attach intrinsically and sacramentally to the poor themselves? This of course is often asserted. And yet, strikingly, Matthew's Jesus seems in the very next chapter to deny any intrinsic identity: 'you always have the poor with you, but you will not always have me' (26.11) - implying at least the possibility of his definitive absence. Evidently there is no ontological equation in the sense that the poor person as such concretely personifies or mediates the presence of Jesus. Relational and analogical puzzles remain, therefore, about how Jesus is present in the act of service and welcoming the poor or children.

All these are difficult questions, and yet Matthew is clearly less troubled by them than are his modern interpreters. In the power of the Father, Jesus is the abidingly gentle one whose burden is light and who refreshes the weary (11.27-30) - a statement that strongly anticipates the authority given to the ever-present Jesus in 28.18. Jesus does exercise a powerful salvific and seemingly timeless presence in the gospel narrative as the one who stills the storm (8.23-27), who steadies the hand of the believer to walk on the turbulent waves (14.28-31), who heals 'all' of those who even touch the hem of his garment (14.36).

\footnotetext{
${ }^{49}$ Cf. S. Coakley, 'Finding Jesus Christ in the Poor', Seeking the Identity of Jesus: A Pilgrimage (ed. B. R. Gaventa and R. B. Hays; Grand Rapids: Eerdmans, 2008), 316.
} 
In these and other passages, it does seem that Matthew in fact happily projects the Jesus of his narrative forward into the life of post-resurrection faith. So too the voice of the exalted Jesus speaks with power to the reader's own experience in 23.34-36, as we have already seen: he is the one who has sought in vain maternally to gather Jerusalem's children

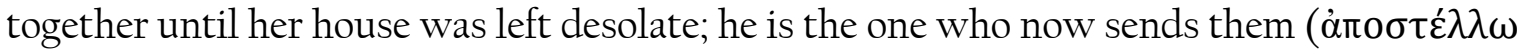

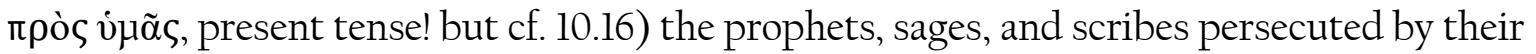
enemies. And he is the one who will return to be greeted by those who anticipate him in Jerusalem.

\section{Sacramental Presence and a Cry of Absence}

Matthew's Last Supper, finally, formulates a richer liturgical setting than Mark, presenting the Passover's bread and wine as the broken body and shed covenant blood of Jesus, here specifically 'for the forgiveness of sins' (26.26-28).

Is this in fact relevant for our question of presence and absence? Unlike Paul (1 Cor 11.25) and perhaps Luke (22.19), Matthew like Mark makes no suggestion that this meal and its interpretation are to be repeated in their own right. Its elements are here not yet selfevidently detachable from that Paschal setting, as somehow intrinsically conveying a continuing presence of Jesus. ${ }^{50}$ This being said, Matthew's last supper does signify and anticipate Jesus's presence with the disciples at a renewed future supper of bread and wine in the kingdom of God (26.29) - even if, notably, the evangelist does not link this future meal to the church's daily or weekly liturgical praxis.

\footnotetext{
${ }^{50}$ Cf. similarly Luz, Matthew, 4:384.
} 
In taking on a Nazirite vow ${ }^{51}$ of abstaining from wine, Jesus himself clearly envisages a period of withdrawal and absence after the Last Supper (27.46). Aside perhaps from the Triduum between Cross and Resurrection, however, Matthew does not particularly develop this theme, suggesting that any absence is confined to this brief and temporary interlude. ${ }^{52}$ Here as elsewhere, Matthew is not systematic.

In some ways the question of an abiding and permanent presence finds its most challenging counterpoint in the question of what 'God with us' might mean at the cross, where the Emmanuel himself cries out that God has forsaken him (27.46). ${ }^{53}$ Matthew leaves this question largely undeveloped, and at one level it is a problem more for the question of where God is now than where Jesus is now. One way to address it would be to affirm that Matthew does not regard even this experience to take away from his unwavering affirmation of Jesus himself as Emmanuel. This is true whether as a crucified victim he pours out his blood 'as a ransom' and 'for the forgiveness' of many $(20.28 ; 26.27)$ or as risen Messiah, with all authority in heaven and earth, commissions the disciples to go to all nations (28.18-20). In Matthew (and by extension perhaps in Mark) it is Jesus's cry of dereliction, rather than (say) his baptism or his exorcisms, which marks the point at which the experience of Jesus is most completely present as Immanu, 'with us.' Here he so entirely encompasses the depth of the human condition, showing that the 'Jesus' who 'saves his people' (1.21) does so precisely by being radically Immanu El (1.23). This ‘embracing’ presence of his death on the cross did not

\footnotetext{
${ }^{51}$ Abstention from wine for a specified period marked the Nazirite, and M. Nazir 2.3 identifies a simple declaration to abstain from a cup set before one as sufficient to validate the vow ( מזגו לו את הכוס, ואמר הריני נזיר ממנו, הרי זה נזיר

52 'We can detect a significant coming absence, but it achieves little focus in Matthew': Nolland, The Gospel of Matthew, 713.

${ }^{53}$ Luz, Matthew, 4:553 (cf. 1:195-96) similarly draws attention to this problem.
} 
escape early commentators, who routinely spoke of Jesus ‘stretching out his hands' in constant care and intercession. ${ }^{54}$ Something of this may also be implicit in Matthew's expanded testimony of the Centurion who, together with his men, takes the accompanying portents to mean that one who died in this way must truly be God's son (27.54).

\section{Conclusion: The Risen Presence}

Matthew is the most unwavering of the evangelists in affirming the personal presence of the living Jesus after Easter in and with the church in its life and mission. That affirmation is for this evangelist not posed with Marcan question marks, nor sublimated by Lucan or Johannine narrative themes of Jesus's departure and substitution by the Spirit as 'another Comforter.'

We have seen that Matthew is aware of a dialectic of absence, but also that he remains content to affirm Jesus as ever-present with his messianic people. This conviction radiates for him both backwards and forwards. Its promise in the birth narrative, like its implementation in his ministry to the fledgling messianic ekklésia, confirms an understanding of the risen Jesus that at no point is somehow less than or inferior to the identity of Emmanuel. Conversely, the emphatic resurrection promise of his presence with 'all power,' 'always,' and 'to the end of the age' inevitably reframes the narrative Gospel parameters in their entirety for readers who return to re-read its beginning from its end.

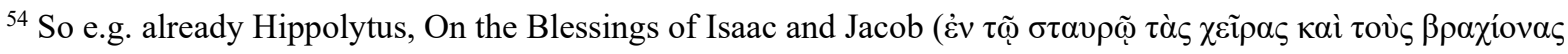
$\dot{\varepsilon} \kappa \pi \varepsilon \tau \alpha \dot{\sigma \alpha \alpha}$, with reference to Isa 53.4: ed. M. Brière et al., Hippolyte de Rome: Sur les bénédictions d'Isaac, de Jacob et de Moïse (PO 27.1-2; Paris: Firmin-Didot, 1954), 20); Arnobius, Comm. on Psalms 17(=18), l. 99 (Haec omnia nobis per illum euenient, qui posuit ut arcum aereum brachia in cruce et cottidie interpellat pro nobis: ed. K.-D. Daur, Arnobii Iunioris Commentarii in Psalmos (CCSL 25.1; Turnhout: Brepols, 1990)); also cf. Justin, Dial. 90.
} 
At the same time, it is quite true that Matthew never articulates precisely how that presence works. He either neglects or refuses to localize that presence with any specifically sacramental focus, or indeed to reserve its spatial location straightforwardly either in heaven or on earth. It is instead both, coming and gaining space 'on earth as it is in heaven. ${ }^{55}$

Nevertheless, between the two endpoints of his great inclusio of 'God with us' (1.23 and 28.20), the cumulative effect of Matthew's narrative description delivers an affirmation of presence that is far stronger and richer than religious commonplaces of anonymous divine providence or assistance. ${ }^{56}$ The same Jesus who was Emmanuel as Mary's child promises his own abiding presence in the church's mission. That mission includes both outreach to the world and internal discernment, and it is manifest especially in the welcome and service of the least of his brothers and sisters. 'Emmanuel' is how he is 'Jesus': 'saving his people' (1.21) is what it means to be 'God with us' (1.23).

${ }^{55} \mathrm{Cf}$. Blumenthal, 'Basileia is Gaining Space'.

${ }^{56}$ So also McDonald, 'I Am with You Always', 85-86. 